\title{
GOOD GOVERNANCE PERSPEKTIF MAQAASID ASY-SYAARI'AH KONTEMPORER
}

\author{
Muhammad Iqbal Juliansyahzen \\ Universitas Islam Negeri Sunan Kalijaga Yogyakarta \\ Jl. Laksda Adisucipto, Sleman, Daerah Istimewa Yogyakarta 55281 \\ E-mail:iqbal.zen21@gmail.com
}

\begin{tabular}{c|c|c}
\hline Received: & Revised: & Approved: \\
$05 / 08 / 2018$ & $17 / 08 / 2018$ & $18 / 08 / 2018$ \\
\hline
\end{tabular}

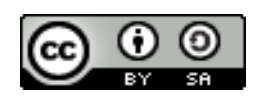

Good Governance Perspektif Maqaasid Asy-Syaari'ah Kontemporer licensed under a Creative Commons Attribution-ShareAlike 4.0 International License

\begin{abstract}
Good governance is a concept for governance that should be run. Theoretically, the discourse of good governance reaps its pros and cons since it had been firstly introduced. However, as a concept and a strategic offer it deserves to be appreciated and re-examined. There are principles in good governance that are compatible with Islam such as accountability, transparency, deliberation, and others. Good governance will be achieved when it involves a good communication among the government, civil society, and the business sector. The author uses the perspective of contemporary maqaasid asy-shari>ah to view the discourse with more emphasis on development and right. The perspective is different from the old maqasid which emphasizes more on the protection and preservation. The result of the study shows that good governace needs harmonious relationship among the followers of religion, social justice, organized and equitable education, human rights protection, and the development of civilized law.
\end{abstract}

Keywords : Good Governance, Maqâsid asy-Syaari'ah, Development. 


\begin{abstract}
Abstrak
Good governance merupakan sebuah konsep tata kelola pemerintahan yang seharusnya dijalankan. Secara teoritis, diskursus good governace menuai pro-kontra sejak awal kemunculannya. Meskipun demikian, sebagai sebuah konsep dan tawaran strategis patut untuk diapresiasi dan dikaji kembali. Terdapat prinsip-prinsip dalam good governance yang berkesesuaian dengan Islam diantaranya akuntabilitas, transparansi, musyawarah, dan lainnya. Upaya mewujudkannya tidak hanya dilakukan oleh satu pihak saja, tetapi komunikasi antara pemerintah (goverment), masyarakat sipil, dan sektor dunia usaha. Dalam melihat diskursus ini, penulis menggunakan perspektif maqaasid asy-Syaari'ah kontemporer dengan lebih menekankan pada development (pembangunan; pengembangan) dan right (hak-hak). Berbeda dengan maqasid lama lebih pada protection (perlindungan) dan preservation (penjagaan; pelestarian). Berdasarkan hasil kajian tersebut bahwa dalam mewujudkan good governace diperlukan pembangunan dalam berbagai aspek seperti membangun hubungan harmonis antar pemeluk agama, mewujudkan keadilan sosial, penyelenggaran dan pemerataan pendidikan, perlindungan terhadap hak asasi manusia, pembangunan hukum berkeadaban..
\end{abstract}

Kata kunci: Good Governance, Maqaasid asy-Syaari'ah, dan Pembangunan.

\title{
A. Pendahuluan
}

Kehadiran konsep tata kelola pemerintahan yang baik atau yang dikenal dengan good governance secara teoritis telah menginspirasi banyak kalangan terutama di negara-negara berkembang, baik di kawasan Asia, Afrika Selatan, maupun Amerika Latin. Konsep ini memberikan gambaran terkait bagaimana suatu lembaga negara khususnya maupun reformasi pemerintahan pada umumnya dikelola dengan baik untuk mewujudkan tujuan pembangunan dan cita-cita demokrasi. Namun konsep ini meninggalkan tantangan serius yaitu, apakah konsep tersebut sesuai dalam kondisi apapun? Kelemahan dasar dari konsep good governance atau tata kelola pemerintahan adalah bagaimana penerapannya pada kawasan negara berkembang, hal ini karena menerapkan peraturan yang disamaratakan, baik negara maju maupun berkembang. Problem tersebut direspon dan bahkan dikritik dengan mengingatkan bahwa memahami realitas reformasi kebijakan, institusi dan keberlangsungan suatu pemerintahan. Hal 
ini karena kebijakan tata kelola pasti mempertimbangkan tuang, kapasitas historis, dan realitas pemerintahan yang dimiliki. ${ }^{1}$

Pembahasan mengenai good governance selalu menarik untuk dikaji dan diteliti lebih lanjut oleh berbagai lintas kepakaran ilmu, baik politik, ekonomi, hukum, sosial-kepemerintahan dan bahkan hukum Islam. Pengelolaan pemerintahan yang baik menjadi perhatian karena pemerintah sangat sentral dalam berbagai sektor pembangunan. Namun demikian, usaha pemerintah dalam mengelola tata pemerintahan yang baik, akuntable, transparan, melalui reformasi birokrasi juga mengalami rintangan dan tantangan yang sangat serius. Di antaranya faktor penghambatnya ialah masih kentalnya praktik korupsi, kolusi dan nepotisme. ${ }^{2}$ Oleh karenanya, perlu upaya penanganan yang sangat serius, baik melalui pendekatan budaya dan khususnya pendekatan agama. Hal ini karena agama memberikan nilai-nilai substantif, tidak hanya bagi individu tetapi juga bagi penyelenggaran negara.

Islam memang tidak memberikan penjelasan rinci tentang bentuk dan pola penyelenggaraan negara, tetapi Islam mengajarkan falsafah nilai yang bertujuan mewujudkan kemashalahatan bagi umat secara umum. Hal inilah yang menjadi tujuan tertinggi pensyariatan Islam. Islam mensyaratkan adanya pemimpin dalam sebuah kelompok, apalagi dalam konteks kenegaraan, perlu adanya pemerintah atau pemimpin. Tanpanya akan terjadi ketimpangan dan kekacauan. Maka, kebutuhan terhadap kehidupan yang baik mensyarakatkan keharusan pemerintah untuk mewujudkan hukum yang adil dan demokratis, dengan istilah lain good governance.

Kajian mengenai good governance perspektif Maqasid Syariah Kontemporer lebih diarahkan pada upaya pendayagunaan maqasid sebagai sistem nilai khususnya dalam penyelenggaraan tata kelola yang baik. Maqasid sebagai basis nilai, sangat potensial untuk menjembatani antara realitas pembangunan dengan peraturan

${ }^{1}$ Syarif Hidayat, "Menimbang Ulang Konsep Good Governance: Diskursus Teoretis," Masyarakat Indonesia 42, no. 2 (19 September 2017): 152, https://doi. org/10.14203/jmi.v42i2.724.

2 Ahmad Zayyadi, "Good Governance Dalam Perspektif Hukum Islam Kontemporer," Al-Manahij: Jurnal Kajian Hukum Islam 11, no. 1 (2017): 14, https:/ / doi. org/10.24090/mnh.v11i1.1265. 
perundangan-undangan dan turunannya. Konsep maqasid dihadirkan untuk melihat apakah realitas pemerintahan termasuk tata kelola dan konteks kerakyatan sudah terjalin secara maqasidi. Artinya, perspektif maqasidi, tidak hanya melihat prioritas tata kelola yang lebih dahulu diperbaiki, namun mengembangkan dan juga membangun, sebagaimana akan diuraikan selanjutnya.

\section{B. Pengertian dan Prinsip Good Governance}

Governance merupakan konsep yang mencakup banyak fenomena terkait dengan pengaturan masyarakat. Awalnya hal tersebut menjadi sebuah alternatif bagi pemerintah untuk melakukan pengendalian. Namun masyarakat tidak dapat dikendalikan. Pengendalian masyarakat semestinya dilakukan oleh aktor sosial. Namun seiring berjalannya waktu para pemikir menyadari bahwa pemerintah seharusnya melakukan apa yang seharusnya dilakukan seperti menciptakan keamanan, melindungi hak milik, mengurangi masalah kemasyarakatan dan mengambil peran utama dalam mengendalikan dan mengarahkan masyarakat.

Berbicara mengenai governance pasti memiliki banyak perbedaan pendapat terkait definisi. Pratikno menjelaskan istilah governance dan government merupakan dua istilah yang digunakan untuk menggambarkan proses pemerintahan. Jika goverment merujuk pada pelaku yaitu pemerintah, maka governance digunakan untuk menyebut pada prosesnya. Secara sederhana Pratikno menjelaskan bahwa governance praktik atau impelementasi dari kerja aktor yaitu goverment. ${ }^{3}$

Istilah Governance kemudian ditambahkan dengan awalan yang normatif oleh para pemikir yaitu "good" yang mengindikasikan minimnya kelalaian dan meningkatnya kriteria untuk pemerintah yang baik sehingga memaksakan agenda pada pemerintah yang sebenarnya sudah kelebihan beban (overload). Pemerintah harus bertindak sesuai dengan kriteria good governance seperti menjamin aturan hukum, akuntabilitas, stabilitas politik, tidak adanya kekerasan,

${ }^{3}$ Pratikno, “'Good Governance' Dan 'Governability,'” Jurnal Ilmu Sosial Dan Ilmu Politik 8, no. 3 (2005): 231-48, https:// doi.org/10.22146/jsp.11043. 
efektivitas, kualitas peraturan, dan pengendalian korupsi (dibuat oleh Bank Dunia). ${ }^{4}$

Adapun definisi mengenai good governance menurut Kofi Annan dalam jabatannya sebagai secretary general of united nation, merujuk pada pemberantasan kemiskinan dan mempromosikan perkembangan. ${ }^{5}$ Adapun Bank dunia dalam laporannya yang berjudul "Pemerintahan dan Pembangunan" mendefinisikan bahwa tata pemerintah yang baik atau good governance adalah cara dimana kekuasan digunakan untuk pengelolaan sumbar daya ekonomi dan sosial suatu negara untuk tujuan pembangunan. ${ }^{6}$ Pendapat lain dikemukakan oleh Michiel de Vries dimana good governance menurutnya adalah tindakan yang tepat dari goverment. Menurut Grindle bahwa adanya good governance adalah sesuatu yang tidak realtistis. ${ }^{7}$

Di antara banyak reformasi tata pemerintahan yang "harus dilakukan", ada sedikit panduan tentang apa yang penting dan apa yang tidak, apa yang harus didahulukan dan apa yang harus diikuti, apa yang bisa dicapai dalam jangka pendek dan apa yang hanya bisa dicapai setelah memerlukan waktu lama, apa yang layak dan mana yang tidak. Jika lebih banyak perhatian diberikan untuk memilah pertanyaan-pertanyaan ini, "pemerintahan yang cukup baik" dapat menjadi tujuan yang realistis bagi banyak negara. ${ }^{8}$ Pemerintahan yang cukup baik (good enough governance) dipandang sebagai pemerintahan yang mendapat nilai tinggi pada faktor-faktor yang penting bagi minimalisasi masalah-masalah kemasyarakatan, meskipun mungkin gagal pada indikator lain dari tata pemerintahan yang baik yang kurang relevan dalam situasi tertentu. ${ }^{9}$

Salah satu faktor penting dalam pemerintahan yang cukup baik (good enough governance) adalah sektor publik yang berfungsi

${ }^{4}$ Michiel de Vries, "The Challenge of Good Governance," The Innovation Journal 18, no. 1 (1 Januari 2013): 1-9.

5 "United Nations University. 2002. Policy Notes. World Governance Assessment (WGA). Diakses pada 28 Juli 2018 pada laman: http:/ / archive.unu.edu/ p\&g/wga/index.html," n.d.

6 "International Fund for Agricultural Development," diakses 17 Agustus 2018, https://www.ifad.org/.

7 Merilee S Grindle, “Good Enough Governance Revisited," Development Policy Review 29, no. S1 (2011): 525 - 548.

${ }^{8}$ Merilee S Grindle, 525 - 548.

${ }^{9}$ Merilee S Grindle, 526. 
dengan baik. Efektivitas pemerintah tidak bergantung pada tindakan para politisi yang hanya mampu mendistorsikan kepercayaan antarpribadi dan institusional dengan membuat janji-janji kosong. Melainkan bergantung pada tingkat yang jauh lebih tinggi yaitu pada kapasitas sektor publik yang dapat memulihkan kepercayaan dengan benar-benar memberikan layanan yang dibutuhkan. Apakah pekerjaan mereka dilakukan atas nama pemerintah agama atau sekuler adalah kepentingan sekunder.

Para ahli tidak bersepakat terhadap bentuk baku suatu pemerintahan dianggap baik dan dapat diaplikasikan di semua negara. Namun, setidaknya suatu pemerintahan yang baik (good governance) memiliki tiga komponen yaitu pemerintah (goverment), masyarakat, dan dunia usaha yang berada di sektor swasta yang sejajar dan berperan saling mengontrol. Oleh karena itu, harus dikemukakan beberapa prinsip yang menandai suatu pemerintahan agar disebut good governance. ${ }^{10}$

Adapun prinsip yang dimaksud adalah pertama, partisipasi masyarakat. Semua masyarakat memiliki kesempatan yang sama untuk berperan serta dalam penyelenggaraan negara baik disampaikan melalui tulisan atau langsung atau melalui forum atau lembaga perwakilan yang sah. Masyarakat memiliki peran mengontrol pemerintahan. Pemerintah tidak dapat mengabaikan masukan rakyat. Kedua, supremasi hukum ditegakkan. Hukum menjadi panglima dan ditegakan secara adil, termasuk yang menyangkut persoalan Hak Asasi Manusia. Ketiga, menjunjung asas transparansi. Ini dibangung diatas kebebasan informasi yang dapat diakses siapapun dan disampaikan dengan ulasan yang lugas agar dapat difahami secara baik. ${ }^{11}$

Bank Dunia mengidentifikasi tiga aspek dari good governance yaitu bentuk rezim politik; proses wewenang dilakukan dalam pengelolaan ekonomi suatu negara dan sumber daya sosial untuk pembangunan; serta kapasitas pemerintah untuk merancang, merumuskan, dan menetapkan kebijakan. Sedangkan untuk dapat menilai aspek-aspek tersebut perlu sebuah penilaian yang memudahkan untuk identifikasi.

\footnotetext{
${ }^{10}$ Zayyadi, "Good Governance Dalam Perspektif Hukum Islam Kontemporer," 16.

11 Zayyadi, 16.
} 
Bank dunia merumuskan empat aspek yang untuk dapat menilai good governance yaitu: 1. manajemen sektor publik. Ini adalah dimensi paling mudah diidentifikasi. Bahasan manajemen sektor publik sebagian besar bersifat teknis, mengubah struktur organisasi dari lembaga sektor untuk tujuan baru, membuat anggaran kerja yang lebih baik, mempertajam tujuan layanan sipil dan menempatkan manajer perusahaan publik di bawah kontrak kinerja. 2. Akuntabilitas. Pemerintah dan karyawannya harus bertanggung jawab atas tindakan mereka. 3. Kerangka hukum untuk pembangunan. Hal tersebut dimaksudkan bahwa sistem hukum yang sesuai harus diciptakan untuk memberikan stabilitas dan prediktibilitas, yang merupakan elemen penting dalam menciptakan suatu lingkungan ekonomi. 4. transparansi dan informasi meliputi pemerintahan yang baik dan memperkuat akuntabilitas. ${ }^{12}$

Pilar penegak good governance memiliki banyak sekali sudut pandang. Beberapa organisasi dunia memberikan ukurannya terkait hal tersebut. Sebut saja World Bank, International Development Association (IDA), The Asian Development Bank (AsDB), The African Development Bank (AfDB), The United Nation Development Programme (UNDP), dan International Fund for Agricultural Development (IFAD). Namun, paling tidak yang cukup representatif ialah apa yang dikategorisasikan oleh IDA sebagai berikut yaitu: ${ }^{13}$

1. Akuntabilitas. Akuntabilitas yang dimaksud dalam hal ini yaitu akuntabilitas Pada tingkat makro seperti akuntabilitas keuangan. Yaitu sistem yang efektif, transparan dan dapat dipertanggung jawabkan secara publik untuk pengendalian pengeluaran dan manajemen kas, dan sistem audit eksternal. Ini mencakup pilihan-pilihan fiskal yang sehat, dibuat dengan cara yang transparan, yang mengutamakan program-program sosial yang produktif - seperti layanan kesehatan dasar dan pendidikan dasar yang penting untuk meningkatkan standar hidup orang miskin dan mempromosikan pembangunan ekonomi - atas pengeluaran non-produktif, seperti belanja militer. Pada tingkat mikro hal tersebut mengharuskan manajer

12 de Vries, "The Challenge of Good Governance," 5.

13 "International Fund for Agricultural Development." 
pelaksana dan lembaga parastatal bertanggung jawab atas efisiensi operasional. Sistem audit harus memenuhi standar internasional dan terbuka untuk pengawasan publik.

2. Transparansi. Maksud dari transparansi adalah transparansi pengambilan keputusan, khususnya dalam proses anggaran, pengaturan dan pengadaan, juga penting untuk efektivitas penggunaan sumber daya dan pengurangan korupsi dan pemborosan.

3. Aturan hukum. Peraturan hukum yang berlaku harus benarbenar diterapkan secara konsisten dan adil. Setiap konflik dapat dipecahkan oleh sistem peradilan yang independen, dan bahwa prosedur untuk mengubah dan membatalkan aturan ada dan diketahui publik.

4. Partisipasi. Good governance mensyaratkan bahwa masyarakat sipil memiliki kesempatan untuk berpartisipasi selama perumusan strategi pengembangan. Serta masyakarat dan kelompok yang terkena dampak langsung dari kebijakan harus dapat berpartisipasi dalam desain dan implementasi program dan proyek. Bahkan jika proyek memiliki dampak sekunder pada daerah atau kelompok populasi tertentu, harus ada proses konsultasi yang mempertimbangkan pandangan mereka. Aspek governance ini merupakan elemen penting dalam mengamankan komitmen dan dukungan untuk proyek dan meningkatkan kualitas pelaksanaannya.

Pilar-pilar penegak good governance yang dirumuskan oleh IDA sama dengan yang disebutkan oleh AsDB. Perbedaan pilar hanya pada satu poin. AsDB menambahkan poin prediktabilitas yaitu hukum dan kebijakan harus ada secara adil dan konsisten untuk mengatur masyarakat.

\section{Maqaashid Asy-Syariah Sebagai Sebuah Perspektif}

Kata maqaashid al-syarii'ah lazim digunakan ushüliyyūn sebagai istilah untuk menyebut sebuah konsep tentang tujuan syariat. ${ }^{14}$

${ }^{14}$ Lihat dalam beberapa artikel yaitu Jasser Auda, Maqaasid Asy-Syaari'ah as Philosophy of Islamic Law; A System Approach, 2007, 2; Dalam versi bahasa Arab Jasser Auda, Maqaasid Asy-Syaari'ah ka Falsafah li at-Tasyri' al-Islamii; Ru'yah Mandzumiyyah 
Adapun secara literal, kata maqaashid merupakan bentuk jamak dari kata maqshid yang berarti tempat tujuan. kata maqaashid merupakan bentuk jamak dari kata maqshid yang berarti tempat tujuan. Kata maqshid berasal dari kata qashd, (qashada, yaqshidu, qashd, fahuwa qaashid). Kata maqshid berasal dari kata qashd, (qashada, yaqshidu, qashd, fahuwa qaashid). Ibn Manzūr memaknai kata qashd dengan arti; tetap pada jalan (istiqaamat al-thariiq). Selain makna di atas, kata qashd juga berarti adil ('adl), atau sikap pertengahan (i'tidaal), yaitu kebalikan dari sikap melampaui batas (ifraat), seperti sikap pertengahan antara boros (israaf) dan kikir (taqtiir). ${ }^{15}$

Ada pun kata al-syarii'ah berasal dari syara'a, yasyra', syar', wa syurü'. Secara etimologis berarti agama (Millah, ad-Dien), jalan (al-tariiqah), yaitu jalan yang ditempuh menuju sumber air untuk diminum. Secara terminologis, kata al-syarii'ah berarti jalan yang lurus yang diridhai Allah bagi hamba-Nya, dan aturan hukum sebagai tatanan bagi hamba-Nya. ${ }^{16}$

Secara lebih rinci, didefinisikan oleh Satria Efendi sebagaimana dikutip Ghofar Sidiq bahwa maqaasid asy-syaari'ah mengandung pengertian umum dan pengertian khusus. Pengertian yang bersifat umum mengacu pada yang dimaksud oleh ayat-ayat hukum atau hadis-hadis hukum, baik yang ditunjuk oleh nash (pengertian kebahasaannya) atau tujuan yang terkandung di dalamnya. Sedangkan pengertian yang bersifat khusus adalah substansi atau tujuan yang hendak dicapai oleh suatu rumusan hukum. ${ }^{17}$ Weal B.

(Beirut: Maktab at-tauzi' fi Alam al-Arabii, 2012), 30; Ahmad Fathan Aniq, "Maqaasid Asy-Syaari'ah wa Makaanatuhaa fii Istinbaati al-Ahkaam Asy-SyarII-ah," Al-Qonun 12, no. 1 (2009): 3; Jasser Auda, Figh al-Maqaasid; Inaathu al-Ahkaam asy-Syar'ìyyah bi Maqaashidihaa (USA: al-Ma'had al-Alaamī lil Fikri al-Islamī, 2007), 15; Jasser Auda, Maqaasid Asy-Syaari'ah; A Beginner's Guide (London: The International Institute of Islamic Thought, 2008), 3-5; Muhammad Saiid bin Ahmad bin Mas'ud al-Yubi, Maqaasid Asy-Syaari'ah al-Islamiyyah wa "Ilaqatuhaa bi al-Adillati asy-Syar"iyyati (Riyadh: Daar al-Hijrah li an-Nasyr wa al-Tauzi', 1998), 13.

${ }^{15}$ Ibn Manzuur, Lisaan al-'Arab, VII (Kairo: Daar al-Hadīth, 2003), 377.

${ }^{16}$ Lebih lanjut baca. Muhammad Saiid bin Ahmad bin Mas'ud al-Yubi, Maqaasid Asy-Syaari'ah al-Islamiyyah, hlm. 29-31.

${ }_{17}$ Muhammad Saiid bin Ahmad bin Mas'ud al-Yubi, Maqaasid Asy-Syaari'ah al-Islamiyyah wa "Ilaqatuhaa bi al-Adillati asy-Syar"iyyati, 29-31. 
Hallaq menyebutkan bahwa maqaasid asy-syaari'ah dengan "universal aims of the law", yakni tujuan universal dari suatu hukum. ${ }^{18}$

Pemabahasan mengenai maslahah menjadi fokus yang terus dikembangkan oleh para juris Islam. Maslahah dipandang sebagai tujuan tertinggi dari pensyariatan Islam (baca: Hukum Islam). Islam sebagai agama yang luhur mencitakan kemashlatan sebagai ending dan tujuan akhir yang ditujukan kepada pemeluk agamanya. Hal ini tercermin dari pengertian agama Islam itu sendiri menurut para ulama yang menyatakan bahwa agama Islam merupakan seperangkat peraturan Ilahi bagi mereka yang memiliki akal yang sempurna untuk memperoleh kebahagian atau kemashlatan baik di dunia maupun di akhirat. Mengingat maslahah sebagai tonggak dalam hukum Islam, maka muncul ungkapan yang terkenal di kalangan ushuliyyun bahwa "dimana ada mashlahah, maka disitulah hukum Allah (ainamaa kaanat al-Mashlahah fa tsamma hukm Allah)." 19

Konsep mashlahah sebagai maksud pensyariatan dalam Islam (Maqaasid Asy-Syaari'ah) mendapatkan perhatian besar dan curahan pemikiran terhadap konsep ini. Menurut Ahmad Raysuni, pemikir asal Maroko, menyatakan bahwa pemikir Islam pertama yang mencurahkan perhatian terhadap Mashalah sebagai maqaasid asy-syaari'ah ialah al-Hakiim al-Turmudhii, ulama yang hidup pada abad ke-3 H. al-Hakiim dikenal sebagai ulama sufi dan juga filosof (sufi philosopher). ${ }^{20}$

Jika dicermati secara mendasar bahwa apa yang diperintah maupun dilarang di dalam al-Quran dan Sunnah yang kemudian juga dirumuskan dalam fikih (hukum Islam) mempunyai tujuan tertentu. Semua memiliki maksud untuk memproteksi manusia sekaligus untuk memberikan kedudukan yang mulia bagi manusia (mashlahah).

${ }^{18}$ Weal B. Hallaq, "Maqaasid and The Challenges of Modernity," Jurnal AlJaami'ah 49, no. 1 (2011): 3.

19 Muhammad Roy P, "Putusan Mahkamah Konstitusi terhadap Pasal 43 Ayat (1) UU No 1 Tahun 1974 Tentang Status Anak di Luar Nikah Berdasarkan Mashlahah Najmuddin Al-thufi (Dekonstruksi Undang-undang Hukum Islam)," Al-Mawarid Journal of Islamic Law 12, no. 1 (2012): 88, https://www.neliti.com/id/ publications/42586/ putusan-mahkamah-konstitusi-terhadap-pasal-43-ayat-1-uu-no1-tahun-1974-tentang.

${ }^{20}$ Ahmad Raysuni, Imam al-Shatibi's Theory of The Higher Objectives and Intens of Islamic Law (London: IIIT, 2011), 5. 
Kemashlahatan sebagai tujuan dari syariat (Maqaasid AsySyaari'ah) oleh Imam Syatibi dibagi menjadi dua sudut pandang, yaitu 1) Maqasid Syaari' (tujuan Tuhan) dan 2) Maqasid al-Mukallaf (tujuan Mukallaf). Maqaasid Asy-Syaari'ah dalam artian Maqasid Syaari', mengandung empat aspek yaitu :21

1. Tujuan awal dari syariat yaitu kemashlatan manusia baik di dunia maupun di akhirat

2. Syariat sebagai sesuatu yang harus dipahami

3. Syariat sebagai suatu hukum taklif yang harus dilaksanakan

4. Tujuan syari'at adalah membawa manusia di bawah naungan hukum.

Aspek pertama berkaitan dengan muatan dan hakikat Maqaasid Asy-Syaari'ah, sedangkan aspek kedua berkaitan dengan dimensi bahasan agar syariat dapat dipahami sehingga tercapai kemashlahatan yang dikandungnya. Aspek ketiga berkaitan dengan ketentuankententuan syariat dalam rangka mewujudkan kemaslahatan. Hal ini juga berkaitan dengan kemampuan manusia untuk melaksanakannya. Aspek keempat berkaitan dengan kepatuhan manusia sebagai mukalaf di bawah dan terhadap hukum-hukum Allah (aspek tujuan syariat berupaya membebaskan manusia dari kekangan hawa nafsu). ${ }^{22}$

Mashlahat sebagai substansi dari maqaasid asy-Syaari'ah dapat dibagi sesuai dengan tinjauannya. Bila dilihat dari aspek pengaruhnya dalam kehidupan manusia, maslahat dibagi menjadi tiga tingkatan $:^{23}$

1. Dharuriyyat, yaitu maslahat yang bersifat primer, dimana kehidupan manusia tergantung padanya, baik aspek duniawi maupun agama. Aspek ini tidak bisa ditinggalkan dalam kehidupan manusia, apabila unsur ini ditinggalkan maka akan terjadi ketimpangan dalam pelbagai aspek kehidupannya. Ini merupakan tingkatan yang paling tinggi. Di dalam Islam, mashlahat dharuriyyat dijaga dengan dua cara yaitu : realisasi dan perwujudannya (jalb al-mashaalih) dan memelihara kelestarian (dar al-mafaasid). Sebagai contoh, yang pertama menjaga agama dengan melestarikan dan melaksanakan kewajiban shalat

${ }^{21}$ La Jamaa, “Dimensi Ilahi dan Dimensi Insani dalam Maqasid al-Syariah," Asy-Syir'ah 45, no. II (n.d.): 1256.

${ }^{22}$ La Jamaa, 1256-57.

${ }^{23}$ La Jamaa, 32-33. 
serta yang kedua menjaga kelestarian agama dengan berjuang terhadap hal-hal yang merusak eksistensi agama itu sendiri. Tingkatan ini memiliki lima unsur penting. Kelima unsur pokok tersebut menurut Imam Asy-Syatibi yaitu diin (agama), nafs (jiwa), nasl (keturunan), 'aql (akal), maal (harta). ${ }^{24}$

2. Hajiyyat, yaitu mashlahat yang bersifat sekunder, yang diperlukan manusia untuk mempermudah dalam kehidupan serta menghilangkan kesukaran maupun kesulitan. Jika tidak ada, maka akan terjadi kesukaran atau kesulitan dalam pemenuhan kebutuhan kehidupan sehari-hari, akan tetapi tidak sampai merusak eksistensi kehidupannya.

3. Tahsiniyyat, yaitu mashlahat yang merupakan moral, dan itu dimaksudkan sebagai pelengkap. Jika tidak ada, maka tidak akan menyulitkan atau bahkan merusak kehidupan seseorang. Tingkatan dibutuhkan dan diperlukan untuk meningkatkan kualitas kehidupan seseorang.

Mata rantai Maqaasid Asy-Syaari'ah sebenarnya tidak dapat dipisahkan dari madzhab Maliki, karena madzhab inilah yang cukup konsep dalam sejarah dan pengembangan maqasid. Madzhab Maliki bermula di Madinah yang dipelopori oleh Malik bin Anas. Secara umum, madzhab mengembangkan pemikiran dengan mengikuti seniornya yaitu Umar bin Khattab. Secara prinsip, prinsip yang membedakan dengan madzhab lainnya ialah prinsip mashlahah al-mursalah. Hubungan antara maqasid dan mashlahah mursalah sangat erat, sebagaimana adagium dari maqasid al-Syariah itu sendiri yaitu jalbu al-masaalih wa dar'u al-mafaasid (mencari kemashlahatan dan menolak kemudlaratan). Pada tahap dan titik ini, ijtihad terhadap fiqh terkodifikasikan di atas konsep dan prinsip ishlah. Hal ini misalnya dalam konteks aplikasi, maka seorang mujtahid dalam memahami dan menafsirkan hukum dari nash bermuara pada prinsip jalbu almasaalih wa dar'u al-mafaasid. Hal ini pula yang diaplikasikan dalam aktivitas qiyas. Tidak saja mengambil dalil mashlahah mursalah terhadap suatu kasus yang tidak didapatkan nashnya, tidak pula

${ }^{24}$ La Jamaa, 32-33. 
kemudian men-qiyas-kannya, melainkan mendatangkan mashlahah dalam memahami nash. ${ }^{25}$

Dalam perkembangannya, Maqaasid Asy-Syaari'ah mengalami pergeseran dalam pendefinisiannya maupun secara orientasi yang saat ini perkembangannya dengan melibatkan social science, filsafat hukum dan lebih bercorak antroposentris. Di antara tokoh kontemporer tersebut diantaranya Abdullah Saeed dengan teori kontekstual dan ethico-legal. Selain itu, Jasser Auda yang menyatakan bahwa Maqaasid Asy-Syaari'ah adalah wisdoms behind rulings (kebijaksaan yang terdapat di balik aturan-aturan) dalam konteks moralitas (morality), universalitas (universality), keadilan sosial (social justice), kemanusiaan (humanity), hak asasi manusia (human right), yang semuanya berorientasi untuk kemashlahatan manusia, tidak hanya kaum Muslim, tetapi juga non-Muslim. ${ }^{26}$ Selain itu, Jasser juga menambah unsur menjaga kehormatan (Irdh).

Jasser juga ingin merekonstruksi konsep maqaașid lama menuju konsep yang lebih baru yang lebih terbuka, elastis, dan damai dalam menjunjung tinggi nilai kemanusiaan. Berikut pergeseran paradigma teori maqasid klasik menuju kontemporer: ${ }^{27}$ Teori Maqasid Klasik: Menjaga Keturunan (al-Nasl); Menjaga Akal (al-Aql); Menjaga kehormatan; menjaga jiwa (al-`Irdh); Menjaga agama (al-Diin); dan Menjaga harta (al-Maal). Sedangkan Teori Maqasid Kontemporer: Teori yang berorientasi kepada perlindungan keluarga; kepedulian yang lebih terhadap institusi Keluarga; Melipatgandakan pola pikir dan research ilmiah; mengutamakan perjalanan untuk mencari ilmu pengetahuan; menekan pola pikir yang mendahulukan kriminalitas kerumunan gerombolan; menghindari upaya-upaya untuk meremehkan kerja otak.; Menjaga dan melindungi martabat kemanusiaan; menjaga dan melindungi hak-hak asasi manusia; Menjaga, melindungi dan menghormati kebebasan beragama atau berkepercayaan; Mengutamakan kepedulian sosial; menaruh

${ }^{25}$ Asmuni Mth, "Studi Pemikiran al-Maqashid (Upaya Menemukan Fondasi Ijtihad Akademik yang Dinamis," Jurnal al-Mawarid XIV, no. 2015 (n.d.): 166.

26 Sanuri, "Signifikan Maqaasid asy-Syaari'ah sebagai kerangka Berfikir Epistemik Ijtihad," Jurnal Islamica: Jurnal Studi Keislaman 8, no. 2 (n.d.): 321.

${ }^{27}$ Amin Abdullah, "Epistemologi Keilmuan Kalam dan Fikih dalam Merespon Perubahan di Era Negara-Bangsa dan Globalisasi (Pemikiran Filsafat Keilmuan Agama Islam Jasser Auda," Jurnal Media Syariah XIV, no. 2 (n.d.): 2012. 
perhatian pada pembangunan dan pengembangan ekonomi; mendorong kesejahteraan manusia; menghilangkan jurang antara miskin dan kaya.

Perubahan paradigma dan teori Maqasid lama ke teori Maqasid baru terletak pada titik tekan keduanya. Titik tekan maqasid lama lebih pada protection (perlindungan) dan preservation (penjagaan; pelestarian), sedangkan teori maqasid baru lebih menekankan pada development (pembangunan; pengembangan) dan right (hakhak). Dalam upaya pengembangan konsep maqasid pada era baru ini, Jasser Auda mengajukan 'human development' sebagai ekspresi obsesinya dan target utama dari maslahah (public interest) masa kini; maslahah inilah yang mestinya menjadi sasaran dari maqaaȘid asysyarii'ah untuk direalisasikan melalui hukum Islam. Perkembangan teori Maqasid dari abad ke abad terutama pada abad ke-20 cukup progresif. Para teoritikus kontemporer mengkritik konsep maqasid tradisional sebagaimana sebelumnya diurai dengan beberapa alasan, antara lain : ${ }^{28}$

1. Jangkauan maqasid tradisional lebih berkaitan dengan individu, dibandingkan keluarga, masyarakat, atau umat manusia.

2. Klasifikasi Maqasid tradisional tidak memasukan nilai-nilai yang paling umum seperti keadilan dan kebebasan

3. Maqasid tradisional dideduksi dari kajian "literatur fikih" ketimbang sumber-sumber syariat (al-Quran dan hadis)

Barulah cendikiawan Muslim modern dan kontemporer memperkenalkan konsep dan klasifikasi maqasid yang baru dan memasukkan dimensi-dimensi Maqasid yang baru guna memperbaiki kekurangan pada konsep maqasid tradisional.

\section{Prinsip "Good Governance" dalam Islam}

Islam sebagai suatu ajaran tentang kehidupan manusia merupakan suatu pandangan yang tidak dapat diperdebatkan lagi di kalangan kaum muslim. Akan tetapi, bagaimana Islam difahami dan diterapkan oleh pemeluknya dalam kehidupan, dalam kontek inilah, terletak persoalan yang sebenarnya. Hal ini dikarenakan Islam sebagai ajaran itu satu (tunggal) tetapi polyinterpretable (pemahaman

${ }^{28}$ Amin Abdullah, 33-34. 
terhadap Islam itu beragam), ${ }^{29}$ termasuk dalam hal penyelenggaraan tata kelola pemerintahan (governance).

Agama sebagai sebuah panduan, pedoman dan penuntun hidup harus difahami secara seksama, tidak dengan pandangan sempit yang pada akhirnya melahirkan pemahaman yang melegalkan untuk berbuat kekerasan dan permusuhan dengan umat dari agama yang berbeda. Bahkan, akibat dari hal tersebut sebagian sosiolog berpendapat bahwa agama di satu sisi menjadi alat pemersatu, tetapi di sisi yang lain menjadi alat pemeca belah, seperti faktor fanatisme agama yang menjadi pemicu perang salib (merugikan kedua belah pihak) ${ }^{30}$ Di sinilah pentingnya mengetahui akar perbedaan sekaligus persamaan yang ada pada agama lain. Umat Islam memang seharusnya perlu untuk membuka diri dan mengembangkan pemahaman terhadap dimensi pluralitas sehingga dapat membaca realitas kemajemukkan secara positif-optimis.

Model dan tata kelola pemerintahan sebenarnya tidak diatur secara eksplisit dalam Islam. Islam menyerahkan kepada manusia dalam pengelolaan pemerintah sesuai dengan realitas sosial, perkembangan zaman, tempat dan kemashlahatan, karena hal itu masuk dalam bagian urusan dunia. Dalam salah satu sabda Nabi disebutkan bahwa "engkau lebih tahu soal urusan dunia kalian", menjelaskan bahwa Islam memberikan ruang kepada manusia untuk mengelola urusan dunianya termasuk dalam tata kelola pemerintahan. Doktrin Islam tidak menekankan model pemerintahan tertentu, maupun mewajibkan umatnya untuk mengikuti dan menganut sistem pemerintahan tertentu untuk memerintah. Islam memberikan kebebasan, ruang untuk mengorganisasi atau mengelola suatu negara (governance) sesuai dengan kebutuhan zaman dan kondisi sosial, ekonomi yang dimiliki. ${ }^{31}$

Secara historis, kehidupan bernegara maupun tata cara pengelolaannya bagi umat Islam baru dimulai setelah Nabi dan pengikutnya berhijrah dan menetap di Madinah. Untuk keperluan

${ }^{29}$ Yusdani, Fiqih Poitik Muslim (Yogyakarta: Amara Books, 2011), 276.

${ }^{30}$ Muhammad Yahya, "Pendidikan Islam Pluralis dan Multikultural," Jurnal Lentera Pendidikan 13, no. 2 (2010): 3.

${ }^{31}$ Muntoha, "Respon Islam terhadap Perubahan Relasi Masyarakat Lokal dan Negara di Indonesia Era Reformasi," Jurnal Wahana Akademika 2, no. 2 (2015): 15, 19. 
pengelolaan negara, Nabi meletakkan prinsip-prinsip dasar yang mengatur kehidupan keluarga,pembagian waris, perdagangan dan jual beli berdasarkan wahyu Ilahi. Kaidah-kaidah pokok perihal kehidupan bermasyarakat, ekonomi, dan budi pekerti, tidak memberikan rincian tentang asas mendirikan negara,dan tidak menyinggung secara langsung sistem pemerintahan dan tata kelolanya. Bahkan, dua ayat (QS. Ali Imran [3] : 159 dan QS. Al-Syura [42] : 38) yang berkaitan dengan perintah syura, tidak diturunkan dalam kaitan sistem dan tata kelola pemerintahan. ${ }^{32}$

Adapun dasar-dasar yang dijadikan pedoman dalam kehidupan individu, bermasyarakat hingga pada bernegara, yang kemudian menjadi titik tolak bagi sistem negara dan juga tata kelola dalam pemerintahan, adalah iman kepada Allah (tauhid). Prinsip dasar ini berimplikasi pada adanya pengakuan prinsip-prinsip persamaan, persaudaraan dan kebebasan. Semua orang mukmin memeliki kedudukan yang sama disisi Allah, yang membedakan diantara mereka adalah taqwa. Prinsip persamaan merupakan nilai dasar yang dijunjung dalam Islam. Tidak ada keutamaan orang Arab atas lainnya, karena seluruh manusia hakikatnya akan menerima balasan sesuai dengan amal perbuatannya. Prinsip dasar inilah yang dilaksanakan dalam pemerintahan periode awal Islam dan pengaruhnya berkembang secara nyata di negara-negara Arab.

Meskipun Islam tidak menetapkan sistem baku dalam mengelola pemerintahan, akan tetapi Islam meletakkan ajaran dasar peradaban manusia yang akan berkembang sepanjang zaman sesuai dengan kebutuhannya. Oleh karena itu, mengatakan bahwa Islam hanya mengurus seputar spiritualitas tanpa bersangkutan dengan persoalan negara, barangkali sama halnya dengan mengatakan bahwa Islam menyediakan seluruh aspek dalam kehidupan termasuk bernegara, sistem politik, ekonomi dan sosial. Namun demikian, bukan berarti al-Quran tidak membawa pesan apapun bagi penyelenggaraan pemerintahan. Pesan yang disampaikan al-Quran lebih bersifat substansial dengan mewarkan nilai etik dan moral

32 Yusdani, Figh Politik Muslim Progresif, (Yogyakarta: Kaukaba, 2015), 170. 
daripada menekan bentuk baku tata kelola dan sistem pemerintahan. Di antara prinsip yang disampaikan al-Quran ialah sebagai berikut $:^{33}$

1. Kekuasaan sebagai amanah

2. Musyawarah sebagai jalan pengambilan keputusan

3. Keadilan harus ditegakkan

4. Adanya prinsip persamaan

5. Pengakuan terhadap Hak Asasi Manusia

6. Perdamaian

7. Kesejahteraan

8. Ketaatan

9. Pengadilan yang bebas (dialog $\mathrm{Mu}^{\prime} \mathrm{adz}$ dengan Nabi)

Maka, berdasarkan prinsip dasar yang disampaikan al-Quran dalam penyelenggaran tata kelola yang baik ternyata selaras dengan prinsip good governance itu sendiri. Keselarasan tersebut misalnya seperti tercermin dalam prinsip keadilan, partisipasi masyarakat sehingga pemerintah tidak otoriter sehingga dijalan berdasarkan prinsip musyawarah, transparasi, akuntabiltas.

\section{E. Kontekstualisasi Good Governance Perspektif Maqasid}

Pada sub ini, penulis mengkontekstualisasikan diskursus good governance melalui perangkat teori maqasid baru yang lebih menekankan pada development (pembangunan; pengembangan) dan right (hak-hak) dibanding maqasid lama lebih pada protection (perlindungan) dan preservation (penjagaan; pelestarian). Dalam konteks penjagaan agama misalnya, tidak hanya mengerjakan perintah dan meninggalkan larangan atau melindungi pemeluk agama dari serangan, tetapi dalam konteks pembangunan menuju good governance upaya penjagaan agama mesti difahami untuk kemashlahatan dan orientasi yang lebih luas yaitu membangun harmoni di tengah perbededaan, begitu seterusnya dalam konteks lainnya. Berikut beberapa kontekstualisasi maqasid kontemporer dalam membangun good governance:

${ }^{33}$ Yusdani, Konfigurasi Pemikiran Politik Islam: Antara Tradisi dan Liberasi (Yogyakarta: PSI UII Kerjasama dengan Rona Pancaran Ilmu, 2016), 59. 


\section{Membangun hubungan Harmonis Antara Pemeluk Agama (Hifdz al-Din)}

Al-Buraey sebagaimana dikutip Rahmad Asril mengatakan bahwa Islam mengakui kebebasan beragama tidak hanya pada tataran teoritis semata, tetapi juga dalam praktis. Protret paling nyata dapat dilihat dari perjanjian Nabi kepada masyarakat Madinah. Setidaknya ada dua asas yang sangat mendasar dalam Piagam Madinah, yaitu pertama, kebebasan beragama dan kedua, asas yang mendasari adanya pemikiran kemanusian dan persaudaraan, asas yang melindungi persamaan hak dan persamaan kewajiban atas segenap individu dan seluruh warga negara. Persamaan hak warga negara yang maksud adalah bahwa tidak ada perbedaan antara masing-masing orang dalam hak dan kewajibannya. Lebih lanjut, persamaan tersebut baik dalam konteks hukum dan peradilan maupun dalam kehidupan sosial. Fakta demikian merupakan realitas yang terjadi pada saat pendirian kota Madinah, manusia memiliki porsi dan kedudukan yang sama yang diwujudkan dalam prinsip kebebasan beragama. ${ }^{34}$

Praktek kepemimpinan Nabi Muhammad SAW merupakan prototype yang berhasil membawa kota Madinah menjadi kota yang terpandang, tersohor, dan terkemuka hingga saat ini. Hijrah yang dilakukan Nabi disebabkan karena memang kala itu ia merupakan sosok yang dibutuhkan untuk mendamaikan suku-suku yang bermusuhan. Anggapan bahwa hijrah nabi sebagai "keputusasaan" dalam menghadapi kebengisan masyarakat Mekkah merupakan anggapan yang keliru. Sehingga, hijrah merupakan bagian dari politik dan strategi dakwah Nabi dalam menciptakan masyarakat yang berperadaban. ${ }^{35}$

Keberadaan Nabi di Madinah membawa misi besar yaitu untuk menyakinkan kepada masyarakat Madinah bahwa Islam memberikan jaminan keamanan terhadap siapa pun yang menerima

${ }^{34}$ Rahmad Asril Pohan, Toleransi Inklusif; Menapak Jejak Sejarah Kebebasan Beragama dalam Piagam Madinah (Yogyakarta: Kaukaba, 2014), 168-69.

35 Hal penting yang harus digarisbawahi adalah bahwa dalam periode Mekkah, dakwah Nabi ditekankan pada aspek penanaman dasar-dasar keimanan. Berbeda dengan di Madinah, Nabi menerapkan syariah Islam dan pembangunan ekonomi sebagai dasar kehidupan bernegara, sehingga Nabi berhasil meletakkan dasar-dasar kemasyarakatan Islam. Lihat. Abdul Karim, Sejarah Pemikiran dan Peradaban Islam (Yogyakarta: Bagaskara, 2012), 68. 
kepemimpinannya. Ia tidak mempersoalkan kedudukan, melainkan memikirkan bagaimana menegakkan kebebasan beragama dan menyatakan pendapat di kalangan masyarakat Madinah sehingga tidak ada lagi orang atau kelompok yang diintimidasi lantaran agama dan pendapatnya. Semua penduduk, tanpa memandang latar belakang agama, akan dapat memperoleh kebebasan yang sama dalam melaksanakan ajaran agama dan mempropagandakan agama masing-masing. ${ }^{36}$

Prinsip-prinsip penyelenggaraan negara berbasis pada nilai toleran di Indonesia pada dasarnya pula mengacu pada Piagam Madinah, terutama terkait aturan kerukunan antar umat beragama. Prestasi Nabi Muhammad Saw dalam menyelesaikan persoalan agama dapat dijadikan cermin dalam menyelesaikan persoalan agama yang terjadi di Indonesia. Secara konstitusional, Indonesia telah menjamin kehidupan beragama bagi seluruh masyarakat Indonesia yang tertuang dalam UUD 1945. Pada batang tubuh UUD 1945 terkait agama memuat pasal 29 yang berisi tentang kebebasan menjalankan syariat agama sesuai dengan kepercayaan masing-masing. ${ }^{37}$

Pembinaan kerukunan antar umat beragama semakin mendapatkan perhatian dari pemerintah dalam hal ini Kementerian Agama. Misal, Mukti Ali, pada tahun 1971 melontarkan gagasan untuk dilakukan dialog agama sebagai salah satu bentuk untuk mempertemukan pemuka-pemuka agama dalam penyelesaian konflik bermotif agama. Perkembangan selanjutnya terjadi pada era H. Alamsyah ratu Prawiranegara yang terus dilanjutkan oleh menteri-menteri selanjutnya. Pada tahun 1978-1984, Alamsyah ratu Prawiranegara pernah menetapkan Tri Kerukunan Beragama sebagai landasan toleransi beragama. Tiga prinsip tersebut adalah kerukunan intern umat beragama, kerukunan antar umat beragama dan kerukunan antar umat beragama dengan pemerintah. ${ }^{38}$

Maka, dalam membangun tata kelola pemerintahan yang baik, hubungan antara berbagai agama yang hidup di suatu negara harus terjalin dengan harmonis. Konsep maqashid syariah kontemporer

\footnotetext{
${ }^{36}$ Abdul Karim, 68.

${ }^{37}$ Rahmad Asril Pohan, Toleransi Inklusif; Menapak Jejak Sejarah Kebebasan Beragama dalam Piagam Madinah, 280-281.

${ }^{38}$ Rahmad Asril Pohan, 281-83.
} 
tidak hanya bermaksud melindungi agama (Islam)nya saja dari ganguan dan lain sebagainya, tetapi juga turut serta dalam melindungi agama-agama lain dari penistaan maupun politisasi agama. Oleh karena itu, untuk mewujudkan kehidupan beragama yang humanis dan toleran sangat dibutuhkan kerjasama antar pemeluk agama.

\section{Mewujudkan Keadilan Sosial (Hifdz al-Maal)}

Suatu pemerintahan yang baik perspektif maqaasid asysyaari'ah kontemporer tidak hanya mewujudkan kesejahteraan pada kalangan tertentu, tetapi harus merata, dapat dirasakan semua kalangan masyarakat. Keadilan sosial merupakan cita-cita umat Islam dalam menjamin kesejahteraan bersama. Bahkan, menurut Nurcholis Madjid, dalam konteks kesejahteraan sosial, cita-cita dalam bidang ekonomi yang dijelaskan secara langsung dalam al-Quran adalah cita-cita keadilan sosial. ${ }^{39}$ Namun demikian, nilai keadilan sosial yang menjadi tujuan bersama sulit untuk diwujudkan jika para pemangku kebijakan atau otoritas tidak menjiwai sila-sila dalam pancasila. ${ }^{40}$

Islam melarang umatnya untuk menumpuk kekayaan dan mendorong mereka dalam pemerataan dengan tidak berpihak pada golongan tertentu. Pemerataan distribusi merupakan salah satu cara untuk mewujudkan keadilan, karena Islam menghendaki kesamaan peluang dalam memperoleh harta. Kebebasan melakukan usaha sesuai kemampuan untuk mencari harta merupakan sakah satu diantara syarat mewujudkan keadilan. Kewajiban untuk mengeluarkan sebagian dari harta yang diperoleh kepada mereka yang kurang beruntung menjadikan redistribusi kekayaan dapat berjalan, dan pemerataan di masyarakat berjalan.

Prinsipnya, distribusi sangat dibutuhkan dalam mewujudkan diperlukan beberapa hal yaitu : kesempatan menikmati sebagi harta dalam pemenuhan kebutuhan hidup, memberikan dampak positif bagi pemberi, khususnya dapat meningkatkan keimanan dan kesadaran untuk berbagi, menebar kebaikan kepada sesama, mengurangi kesenjangan di antara masyarakat, memberikan harapan bagi orang

${ }^{39}$ Nurcholis Madjid, Islam Kemoderanan dan Keindonesiaan (Bandung: Mizan, 1994), 101.

${ }^{40}$ M. Sidi Ritaudin, "Fatwa Keadilan Sosial: Tawaran Resolusi Konflik Horizontal dalam Negara Majemuk," Jurnal Analisis XII, no. 2 (2012): 344. 
lain dalam menghadapi kehidupan. Terlebih secara maqasidi, dengan memprioritaskan golongan masyarakat yang berkategori miskin dan fakir. ${ }^{41}$ Hal karena dalam salah satu riwayat disebutkan baha kefakiran dapat mendekatkan seseorang pada kekafiran. Upaya penyelamatan dari kekafiran (menjaga agama) juga menjadi agenda prioritas dalam Islam, dan pemerintah wajib melindungi terhadap persoalan ini.

Keadilan merupakan salah satu esensi dari ajaran Islam. ia juga merupakan ekspresi dan tujuan hak asasi manusia, oleh karenanya, pembahasan mengenai keadilan bersangkutan dengan pemenuhan terhadap hak-hak fundamental bagi manusia secara umum tanpa diskriminasi. Kemajemukan yang ada di suatu negara bukan menjadikan mereka menindas kelompok lainnya. Di antara isu krusial dalam permasalahan keadilan sosial ialah tentang pemenuhan hak-hak minoritas dan perempuan. Bahkan menurut Abou El Fadl menegaskan bahwa tidak ada tirani mayoritas terhadap minoritas, baik minoritas agama, suku, bahasa, dan lainnya. Sistem pemerintahan dan tata kelola harus menjamin hak minoritas dan mengembalikannya pada prinsip-prinsip etis dan moral Islam. ${ }^{42}$

Pemerintah wajib menyelenggarakan pemerintahan yang berorientasi pada pemerataan keadilan bagi seluruh warganya. Ketimpangan acapkali terjadi khususnya di perkotaan dan di pulaupulau tertentu. Golongan dan kelompok tertentu sangat berlimpah harta kekayaan, namun di sisi yang lain terdapat banyak kelompok masyarakat yang berada di bawah garis kemiskinan. Artinya, penyelenggaraan pemerintahan yang baik (good governance) perspektif maqasidi belum terwujud. Padahal dalam konteks keindonesiaan, keadilan sosial termaktub secara jelas dalam sila dalam pancasila yang menjadi pandangan hidup bangsa Indonesia.

\section{Penyelenggaran dan Pemerataan Pendidikan (Hifdz al-'Aql)}

Menurut perspektif maqasid kontemporer, penjagaan terhadap akal tidak hanya sebatas pelarangan terhadap hal-hal yang memabukkan sehingga hilang kesadaran, namun lebih dari itu yaitu

${ }^{41}$ Ruslan Abdul Ghofur Noor, "Kebijakan Distribusi Ekonomi Islam dalam Membangun Keadilan Ekonomi di Indonesia," Jurnal Islamica 6, no. 2 (2012): 323.

${ }^{42}$ Abid Rohamnu, "Pluralisme, Demokrasi dan Keadilan Sosial dalam Konsepsi Fiqh Humanistik Abo u El Fadl," Jurnal Islamica 4, no. 1 (2009): 29. 
mewujudkan generasi yang berpendidikan. Negara bertindak sebagai aktor dalam penyelenggaraan dan pemerataan pendidikan.

Penyelenggaraan dan pemerataan pendidikan merupakan bagian dari hak asasi manusia yang menjadi tanggung jawab negara. Hak ini tidak dapat dikurangi. Dalam konteks UUD 1945, kewajiban ini menyebutkan sebagai bagian dari Hak Asasi Manusia (HAM). Hal ini sebagaimana disebutkan dalam Undang-Undang No. 32 Tahun 2004 dan PP Nomor 25 tahun 2005) bahwa setiap warga negara Indonesia berhak mendapatkan pendidikan dan pengajaran tanpa terkecuali.

Dalam konteks Indonesia, UUD merupakan rujukan baku bagi kehidupan berbangsa dan bernegara. Di dalamnya, telah dijamin kebutuhan warga dan khususnya anak-anak yang kurang mampu. Padahal secara jelas konstitusi negara Indonesia mengamanatkan sebagaimana tertuang dalam pasal 34 dan 38, namun tetap banyak anak-anak yang tidak mendapatkan pendidikan dan terlantar yang pada akhirnya tingkat kriminalitas meningkat. Akses pendidikan yang kurang tersebar dan merata menjadi salah satu faktor anak-anak tidak mendapatkan pendidikan. ${ }^{43}$ Karena itu, Pemerataan pendidikan menjadi agenda yang harus dilaksanakan pemerintah sebagai bagian dari pembangunan nasional.

Problem lain yang mengakibatkan pendidikan tidak dapat dirasakan semua kalangan meskipun pemerintah telah meningkatkan biaya APBN sebesar 20\% ialah terkait ketatnya persyaratan memasuki bangku sekolah yang semakin ketat dan kompleks. Problem tersebut diperparah dengan komersialisme pendidikan yang tentu semakin menutup akses pendidikan bagi kelompok-kelompok masyarakat tertentu. ${ }^{44}$

Maka, dalam membantu mewujudkan pembangunan nasional dari sektor pendidikan, pemerintah harus melakukan reformasi pendidikan secara lebih serius lagi, baik dengan penambahan alokasi APBN, menggiatkan gerakan literasi, memperbaiki sarana-prasarana serta infrastruktur dan lain sebagainya.

${ }^{43}$ Lukman Hakim, "Pemerataan Akses Pendidikan Bagi Rakyat Sesuai dengan Amanat Undang-Undang Nomor 20 Tahun 2003 tentang Sistem Pendidikan Nasional," Jurnal EduTech 2, no. 1 (2016): 62.

${ }^{44}$ Mujahidun, "Pemerataan Pendidikan Anak Bangsa: Pendidikan Gratis Versus Kapitalisme Pendidikan," Jurnal Tarbiyatuna 7, no. 1 (2016): 41. 


\section{Perlindungan terhadap Hak Asasi Manusia (Hifdz al-Ird)}

Hak Asasi Manusia (HAM) merupakan hak dasar yang diberikan Tuhan Yang Maha Esa kepada setiap manusia sematamata karena ia manusia. Umat manusia memilikinya bukan karena pemberian masyarakat atau hukum positif, melainkan semata-mata berdasarkan martabatnya sebagai manusia dari Tuhan Yang Maha Kuasa. Berdasarkan pemahaman tersebut, maka perbedaan warna kulit, jenis kelamin, suku, budaya maupun kewarganegaraan tidak dapat menghilangkan hak-hak tersebut dari manusia. Inilah sifat universal dari hak-hak tersebut. Selain sifat universal, HAM juga tidak dapat dicabut (inalienable). Artinya seburuk apapun perlakuan terhadap seseorang, hak-hak orang tersebut tidak lantas tercerabut begitu saja. ${ }^{45}$

Dalam rumusan Undang-Undang No. 39 Tahun 1999 mengenai Hak Asasi Manusia disebutkan "hak asasi manusia merupakan hak dasar yang secara kodrati melekat pada diri manusia, bersifat universal dan langgeng, oleh karena itu harus dilindungi, dihormati, dipertahankan, dan tidak boleh diabaikan, dikurangi, atau dirampas oleh siapa pun." ${ }^{46}$ Lebih lanjut ditegaskan pada UndangUndang yang sama pada pasal 1 disebutkan bahwa "Hak Asasi Manusia adalah seperangkat hak yang melekat pada hakikat dan keberadaan manusia sebagai makhluk Tuhan Yang Maha Esa dan merupakan anugerahNya yang wajib dihormati, dijunjung tinggi dan dilindungi oleh negara hukum, pemerintahan, dan setiap orang demi kehormatan serta perlindungan harkat dan martabat manusia.

Penghormatan terhadap eksistensi hak-hak manusia tersebut sejalan dengan visi hadirnya Islam yaitu menegakkan keadilan dan hak asasi manusia, terutama pembelaan terhadap kaum yang lemah. Misalnya, Islam datang untuk menghapus kelas dan diskriminasi bagi kaum perempuan sebagai subjek yang kerap kehilangan hak-haknya.

${ }^{45}$ Suparman Marzuki, DKK, ed., Hukum Hak Azasi Manusia (Yogyakarta: PUSHAM UII, 2010), 11.

${ }^{46}$ Konsideran "menimbang" huruf b. Diantara hak-hak yang dijamin meliputi hak untuk hidup, hak berkeluarga dan melanjutkan keturunan, hak untuk mengembangkan diri, hak untuk memperoleh keadilan, hak atas kebebasan pribadi, hak atas rasa aman, hak atas kesejahteraan, hak untuk turut serra dalam pemerintahan, hak perempuan, hak anak. Pembahasan mengenai masing-masing dapat dibaca lebih lanjut pada. Lihat. Suparman Marzuki, DKK, 256-170. 
Hak-hak rakyat merupakan sesutau yang mesti harus dijamin oleh pemerintah, karena hak rakyat merupakan prasarat mewujudkan pemerintahan yang baik dan demokratis, ${ }^{47}$ atau dengan istilah lainnya disebut good governance.

Jika dirunut dalam Islam, sebetulnya falsafah dasar dari HAM adalah tauhid. Tauhid sebagai sebuah prinsip dasar dalam Islam mengandung arti bahwa hanya ada satu pencipta bagi alam semesta. Dalam tauhid terkandung ide persamaan dan persaudaraan seluruh manusia. Bahkan, tauhid mencakup ide persamaan dan persatuan semua makhluk. Paling tidak, terdapat 14 buah hak asasi dalam Islam sebagai acuan dalam penyelenggaran tata kelola pemerintahan yang baik yaitu: (1) Hak memperoleh perlindungan hidup; (2) hak memperoleh keadilan (3) hak memperoleh persamaan perlakuan (4) kewajiban mengikuti apa yang benar dan meninggalkan apa yang tidak benar dalam kaca mata hukum (5) hak ikut serta dalam kehidupan bermasyarakat dan bernegara (6) hak memperoleh kemerdekaan (7) hak memperoleh kebebasan dari pengejaran dan penuntutan (8) hak menyatakan pendapat (9) hak atas perlindungan terhadap penuntutan atas dasar perbedaan agama (10) hak memperoleh ketenangan perorangan (privacy) (11) Hak-hak ekonomi, termasuk memperoleh pekerjaan dan mendapatkan imbalan atasnya (12) hak mendapatkan perlindungan atas kehormatan dan nama baik (13) hak atasharta benda dan milik (14) hak memperoleh imbalan yang pantas dan penggantian yang sesuai. ${ }^{48}$

Maka, upaya mewujudkan good governance dalam sudut pandang perspektif maqasid kontemporer tidak hanya menjaga jiwa manusia tetapi lebih dari itu menjaga dan melindungi martabat kemanusiaan secara lebih umum; menjaga dan melindungi hak-hak asasi manusia, sebagaimana diurai sebelumnya.

\section{Pembangunan Hukum Berkeadaban}

Suatu pemerintahan yang baik (good governance) hanya akan terwujud jika didasarkan pada dua hal yaitu kedaulatan hukum dan keadilan dalam hubungan internasional. Pembangunan hukum

${ }^{47}$ Ellya Rosana, "Negara Demokrasi dan Hak Asasi Manusia," Jurnal Tapis 12, no. 1 (n.d.): 46.

${ }^{48}$ Yusdani, Fiqih Poitik Muslim, 298. 
merupakan upaya sadar dan sistematis dan berkesinambungan untuk membangun kehidupan bermasyarakat, berbangsa dan bernegara. Semua elemen masyarakat hidup rukun, berdampingan, sejahtera dan dalam kepastian hukum. Dalam konteks Indonesia, pelaksanaan pembangunan tersebut merupakan upaya dalam mencapai tujuan negara sebagaimana yang termaktub dalam alenia keempat UUD 1945, yaitu melindungi segenap bangsa dan seluruh tumpah darah Indonesia, memajukan kesejahteraan umum, mencerdaskan kehidupan bangsa dan ikut melaksanakan ketertiban dunia berdasarkan kemerdekaan, perdamaian abadi dan keadilan sosial. ${ }^{49}$

Persoalan mendasar dan terbesar pembangunan hukum di Indonesia yaitu adanya kesenjangan antara Undang-Undang 1945, yang secara konten sudah sangat jelas berisi atas keadilan sosial dan ditujukan untuk kemakmuran dan kesejahteraan masyarakat, dengan garis politik dan perundang-undangan yang menyusul di bawahnya. Mencuatnya isu keadilan sosial dan paradigma kerakyatan ke permukaan menjadi penanda bahwa persoalan di masyarakat begitu kompleks sehingga tawaran paradigma tersebut dapat dipergunakan dalam menata sistem termasuk perimbangan kekuasaan antara pemerintah pusat dan daerah-daerah. ${ }^{50}$

Melihat persoalan tersebut, maka kiranya perlu mereorientasi pembangunan hukum dalam pengelolalan pemerintah yang baik (good governance) meliputi, pertama, masalah reaktualisasi sistem hukum yang bersifat netral dan berasal dari hukum lokal (adat) ke dalam hukum nasional dan juga hukum lain yang bersumber pada perjanjian-perjanjian internasional yang telah disepakati dan diakui. Kedua, masalah penataan kelembagaan aparatur hukum yang masih mengedepankan egoisme sektoral, miskomunikasi dan miskoordinasi antar berbagai lembaga penegak hukum. Ketiga, masalah pemberdayaan masyarakat secara khusus yang mengedepankan pada partisipasi publik dalam pembangunan dan akses informasi publik terhadap kinerja birokrasi. Kedua hal ini dapat pula dikelompokan sebagai "budaya hukum". Kedua piranti harus difahami dan dilaksanakan

49 Wicipto Setiadi, "Pembangunan Hukum dalam Rangka Peningkatan Supremasi Hukum," Jurnal RechtsVinding: Media Pembinaan Hukum Nasional 1, no. 1 (n.d.): 6.

${ }^{50}$ Wicipto Setiadi, 7. 
dengan baik, karena tanpa adanya kedua piranti tersebut hukum tidak dapat difahami secara benar atau jika dapat difahami tetapi tidak dapat ditempatkan pada kondisi dan tempat yang selayaknya dalam konteks persepsi dan pandangan masyarakat. ${ }^{51}$

Pembangunan hukum berkeadaban secara maqasidi memang tidak bisa dipisahkan antar satu elemen dengan elemen lainnya. Unsur pemerintah sebagai pelaksana (goverment), hukum itu sendiri, akses informasi, supremasi hukum maupun kontrol masyarakat harus saling berkaitan. Perspektif maqasidi mengharuskan bahwa satu elemen atau unsur harus saling berkomunikasi sehingga pembangunan hukum dapat terwujud dengan baik.

\section{F. Simpulan}

Diskursus good governance selalu menjadi kajian yang menarik dari berbagai kalangan. Meskipun secara teoritis khususnya di Dunia Barat, konsep ini menuai pro-kontra. Tetapi hal itu adalah wajar dalam diskursus sebuah tawaran strategis. Namun demikian, indikator yang disampaikan menunjukan bahwa secara prinsip dasar penyelenggaraan suatu pemerintahan yang baik telah berkesesuaian dengan prinsip dasar dalam Islam. Prinsip-prinsip akuntabilitas, transparansi, keterbukaan dan kontrol masyarakat merupakan prinsip yang juga diajarkan dalam Islam. Islam sebagai sebuah ajaran memang tidak memberikan sistem baku bagi penyelenggaraan pemerintah. Islam hanya memberikan seperangkat nilai etis yang dapat disesuaikan dengan realitas zaman dan kondisi.

Untuk melihat diskusus ini, penulis menggunakan sebuah perspektif maqaasid asy-syariiah kontemporer. Jika maqasid lama lebih pada protection (perlindungan) dan preservation (penjagaan; pelestarian), maka dalam konteks maqasid baru atau kontemporer berorientasi pada pembangunan dan pengembangan (development). Tata kelola pemerintahan yang baik tidak hanya berfokus pada penjagaan dan pengamanan sekelompok saja, tetapi lebih meluas pada pemerataan dan pembangunan di berbagai sektor. Dalam konteks penjagaan agama misalnya, tidak hanya mengerjakan perintah

${ }^{51}$ Romli Atmasasmita, "Tiga Paradigma Hukum dalam Pembangunan Nasional," Jurnal Hukum Prioris 3, no. 1 (n.d.): 12. 
dan meninggalkan larangan atau melindungi pemeluk agama dari serangan, tetapi dalam konteks pembangunan menuju good governance upaya penjagaan agama mesti difahami untuk kemashlahatan dan orientasi yang lebih luas yaitu membangun harmoni di tengah perbededaan, begitu seterusnya dalam konteks pembangunan di bidang lainnya[.]

\section{REFERENSI}

Abdul Karim. Sejarah Pemikiran dan Peradaban Islam. Yogyakarta: Bagaskara, 2012.

Abid Rohamnu. "Pluralisme, Demokrasi dan Keadilan Sosial dalam Konsepsi Fiqh Humanistik Abo u El Fadl." Jurnal Islamica 4, no. 1 (2009).

Abu Ishaq Asy-Syatibi. al-Muwaafaqaat fi ushîl asy-Syari'ah. II. Beirut: Dar Kutub al-Ilmiyyah, n.d.

Ahmad Fathan Aniq. "Maqaasid Asy-Syaari'ah wa Makaanatuhaa fii Istinbaati al-Ahkaam Asy-SyarII-ah." Al-Qonun 12, no. 1 (2009).

Ahmad Raysuni. Imam al-Shatibi's Theory of The Higher Objectives and Intens of Islamic Law. London: IIIT, 2011.

Amin Abdullah. "Epistemologi Keilmuan Kalam dan Fikih dalam Merespon Perubahan di Era Negara-Bangsa dan Globalisasi (Pemikiran Filsafat Keilmuan Agama Islam Jasser Auda." Jurnal Media Syariah XIV, no. 2 (n.d.): 2012.

Asmuni Mth. "Studi Pemikiran al-Maqashid (Upaya Menemukan Fondasi Ijtihad Akademik yang Dinamis." Jurnal al-Mawarid XIV, no. 2015 (n.d.).

Ellya Rosana. "Negara Demokrasi dan Hak Asasi Manusia." Jurnal Tapis 12, no. 1 (n.d.): 2016.

Ghofar Shidiq. "Teori Maqaasid Asy-Syaari'ah dalam Hukum Islam." Jurnal Sultan Agung XLIX, no. 118 (2009).

Hidayat, Syarif. "Menimbang Ulang Konsep Good Governance:

Diskursus Teoretis." Masyarakat Indonesia 42, no. 2 (19 
September 2017): 151-65. https://doi.org/10.14203/jmi. v42i2.724.

Ibn Asyur. Maqaashid Asy-Syarii'ah al-Islaamiyyah. Tunis: Dar Sukhnūn lin-Nasyr wa At-Tauzi', 2014.

Ibn Manzuur. Lisaan al-'Arab. VII. Kairo: Daar al-Hadīth, 2003.

"International Fund for Agricultural Development." Diakses 17 Agustus 2018. https://www.ifad.org/.

Jasser Auda. Figh al-Maqaasid; Inaathu al-Ahkaam asy-Syar'iyyah bi Maqaashidihaa. USA: al-Ma'had al-Alaamī lil Fikri alIslamī, 2007.

-Maqaasid Asy-Syaari'ah; A Beginner's Guide. London: The International Institute of Islamic Thought, 2008.

-------Maqaasid Asy-Syaari'ah as Philosophy of Islamic Law; A System Approach, 2007.

-Maqaasid Asy-Syaari'ah ka Falsafah li at-Tasyri' al-Islamii; Ru'yah Mandzumiyyah. Beirut: Maktab at-tauzi' fi Alam alArabii, 2012.

La Jamaa. "Dimensi Ilahi dan Dimensi Insani dalam Maqasid alSyariah." Asy-Syir'ah 45, no. II (n.d.): 2011.

Lukman Hakim. "Pemerataan Akses Pendidikan Bagi Rakyat Sesuai dengan Amanat Undang-Undang Nomor 20 Tahun 2003 tentang Sistem Pendidikan Nasional." Jurnal EduTech 2, no. 1 (2016).

M. Sidi Ritaudin. "Fatwa Keadilan Sosial: Tawaran Resolusi Konflik Horizontal dalam Negara Majemuk." Jurnal Analisis XII, no. 2 (2012).

Merilee S Grindle. “Good Enough Governance: Poverty Reduction and Reform in Developing Countries. Governance." Governance 17, no. 4 (2004): 525-48.

---_--_Good Enough Governance Revisited.” Development Policy Review 29, no. S1 (2011): 199-221.

Muhammad Roy Purwanto. Dekontruksi Hukum Islam, Krtitik terhadap Teori Mashlahah Najmuddin at-Tufi. Yogyakarta: Kaukaba Dirgantara, 2014. 
--Kritik terhadap Konsep Mashlahah Najmuddin at-Tufi, Disertasi." Pasca Sarjana UIN Sunan Kalijaga Yogyakarta, n.d.

Muhammad Saiid bin Ahmad bin Mas'ud al-Yubi. Maqaasid AsySyaari'ah al-Islamiyyah wa "Ilaqatuhaa bi al-Adillati asy-Syar"iyyati. Riyadh: Daar al-Hijrah li an-Nasyr wa al-Tauzi', 1998.

Muhammad Yahya. "Pendidikan Islam Pluralis dan Multikultural." Jurnal Lentera Pendidikan 13, no. 2 (2010).

Mujahidun. "Pemerataan Pendidikan Anak Bangsa: Pendidikan Gratis Versus Kapitalisme Pendidikan." Jurnal Tarbiyatuna 7, no. 1 (2016).

Muntoha. "Respon Islam terhadap Perubahan Relasi Masyarakat Lokal dan Negara di Indonesia Era Reformasi." Jurnal Wahana Akademika 2, no. 2 (2015).

Nurcholis Madjid. Islam Kemoderanan dan Keindonesiaan. Bandung: Mizan, 1994.

P, Muhammad Roy. "Putusan Mahkamah Konstitusi terhadap Pasal 43 Ayat (1) UU No 1 Tahun 1974 Tentang Status Anak di Luar Nikah Berdasarkan Mashlahah Najmuddin Al-thufi (Dekonstruksi Undang-undang Hukum Islam)." Al-Mawarid Journal of Islamic Law 12, no. 1 (2012). https://www.neliti. com/id/publications/42586/putusan-mahkamah-konstitusiterhadap-pasal-43-ayat-1-uu-no-1-tahun-1974-tentang.

"Policy Notes. World Governance Assessment (WGA)." United Nations University, n.d. Diakses 28 Mei 2018.

Pratikno, -. "'Good Governance' Dan 'Governability.'” Jurnal Ilmu Sosial Dan Ilmu Politik 8, no. 3 (2005): 231-48. https://doi. org/10.22146/jsp.11043.

Rahmad Asril Pohan. Toleransi Inklusif; Menapak Jejak Sejarah Kebebasan Beragama dalam Piagam Madinah. Yogyakarta: Kaukaba, 2014.

Romli Atmasasmita. "Tiga Paradigma Hukum dalam Pembangunan Nasional." Jurnal Hukum Prioris 3, no. 1 (n.d.): 2012.

Ruslan Abdul Ghofur Noor. "Kebijakan Distribusi Ekonomi Islam dalam Membangun Keadilan Ekonomi di Indonesia." Jurnal Islamica 6, no. 2 (2012). 
Sanuri. "Signifikan Maqaasid asy-Syaari' ah sebagai kerangka Berfikir Epistemik Ijtihad." Jurnal Islamica : Jurnal Studi Keislaman 8, no. 2 (n.d.): 2014.

Suparman Marzuki, DKK, ed. Hukum Hak Azasi Manusia. Yogyakarta: PUSHAM UII, 2010.

“United Nations University. 2002. Policy Notes. World Governance Assessment (WGA). Diakses pada 28 Juli 2018 pada laman: http:/ / archive.unu.edu/p\&g/wga/index.html," n.d.

Vries, Michiel de. "The Challenge of Good Governance." The Innovation Journal 18, no. 1 (1 Januari 2013): 1.

Weal B. Hallaq. "Maqaasid and The Challenges of Modernity." Jurnal Al-Jaami'ah 49, no. 1 (2011).

Wicipto Setiadi. "Pembangunan Hukum dalam Rangka Peningkatan Supremasi Hukum." Jurnal RechtsVinding: Media Pembinaan Hukum Nasional 1, no. 1 (n.d.): 2012.

Yusdani. Figh Politik Muslim Progresif,. Yogyakarta: Kaukaba, 2015.

------Fiqih Poitik Muslim. Yogyakarta: Amara Books, 2011.

------Konfigurasi Pemikiran Politik Islam: Antara Tradisi dan Liberasi. Yogyakarta: PSI UII Kerjasama dengan Rona Pancaran Ilmu, 2016.

Zayyadi, Ahmad. "Good Governance Dalam Perspektif Hukum Islam Kontemporer." Al-Manahij: Jurnal Kajian Hukum Islam 11, no. 1 (2017): 13-34. https://doi.org/10.24090/mnh.v11i1.1265. 